\title{
Formy, detale i współczesne znaczenia polskiej architektury betonowej
}

\section{Forms, details and contemporary meanings of polish concrete architecture}

\section{Streszczenie}

Artykuł podejmuje próbę przedstawienia związku między ideami architektonicznymi a betonem jako materią w tworzeniu polskiej architektury na początku XXI wieku. Pierwsza część tekstu przedstawia przykłady, w których doskonałość architektury postrzegana jest nie tylko w odwołaniu do racjonalizmu architektury XX wieku, lecz także w związku z tym, co można by zdefiniować jako poszukiwanie estetyki w odpowiednich formach wyrazu. Druga część pokazuje przykłady, w których doskonałość architektury wiąże się nie tylko z zasadami metafory architektury XX wieku, ale także z tym, co definiujemy jako poszukiwanie estetyki w odpowiedniej geometrii form.

Słowa kluczowe: architektura betonowa, idea, materiał, ekspresjonizm

\begin{abstract}
The article is an attempt to show the relationship between architectural ideas and concrete matter in the Polish architecture of the beginning of the 21st century. The first part shows examples in which the perfection of architecture is associated not only with the rational principles of 20th century architecture, but also with what we define as the search for aesthetics in the appropriate expression of forms. The second part shows examples in which the perfection of architecture is associated not only with the metaphor principles of 20th century architecture, but also with what we define as the search for aesthetics in appropriate geometry of forms.
\end{abstract}

Keywords: concrete architecture, idea, matter, expressionism 


\section{ARCHITEKTURA BETONOWA}

Betonowe narracje we współczesnej architekturze nie są jednoznaczne. Można by rzec, że beton i jego formy są powodem wszelakich odczuć, powodujących skrajne emocje i reakcje estetyczne. W ciągu wieku mit materiału nowoczesnego, służącego budowaniu „nowego świata", został wielokrotnie zanegowany wyobrażeniem o rzeczy brzydkiej, niedoskonałej i nudnej. Dziś jednak owa nowość i nieoczywistość stanowią jedną z najbardziej znaczących cech, które przystały do betonu. Mieszanina wody, cementu i kruszywa, od czasu kiedy była jeszcze materią „nienazwaną”, przeobraziła się w „kamień filozoficzny”, który zamienia mulistą masę w kruszec odkrywający kolejne znaczenia i sensy stylistyczne architektury.

Podstawowa metafora betonu jest ustalona i wynika po części ze specyfiki kodu wizualnego oraz jego znaczeń - beton naśladuje kamień - może mieć jego właściwości optyczne, dotykowe i techniczne. Jedność kamienia i betonu została określona na początku XX wieku przez Auguste'a Perreta przez pierwsze porównanie betonu do „odmłodzonego kamienia” [pierre rajeuni]. Metaforę tę odkrył, wzmocnił i rozpowszechnił Le Corbusier po wybudowaniu Jednostki Marsylskiej, w której beton przyjął właściwości naturalnej skały - twórca twierdził: „beton jest odtworzonym kamieniem, wartym eksponowania w swoim stanie naturalnym”. Inny z wielkich modernistów, Louis Kahn, w czasie budowy Salk Institute zdefiniował beton jako „lany kamień” [liquide stone] lub „drążony kamień” [hollow stone], a więc materiał, który przejmuje wszystkie jego konstytutywne cechy - twardość, fakturę, poetykę, symbolikę, mitologię.

Dziś nadal dla wielu architektów beton jest „kamieniem współczesności”, „materią bez wad kamienia". Beton wciąż jest nośnikiem wszelakich idei architektury i stanowi kwintesencję materialności - jest tworzywem, którego sekret ujawnia się w wiedzy technicznej i technologicznej, w „tajemnicy” odkrywanej metodą logicznego i naukowego działania, której uzus jest nadawany przez kolejne konotacje. Beton staje się dla architekta celem samym w sobie - stwarza go w wyobraźni z potrzeby ukazania formy i znaczenia jego właściwości fizycznych oraz estetycznych. Wyborom substancji towarzyszy zawsze wybór techniki wykonania rzeczy, zaś szalunek betonu jawi się jako matryca dla formy będącej „pozytywem” wyobrażenia architekta. Jest także „naładowany” nie tylko energią, prawami czy potencja, ale różnorodnym sposobem artystycznego i przedartystycznego opracowania.

Beton jako budulec nie istnieje jednak samodzielnie. Frank Lloyd Wright uważał, że beton to kamień stworzony $w$ formie, zatem to forma szalunku - nadrzędnie obrana forma w umyśle twórcy nadaje sens estetyczny i techniczny architekturze. Ów status betonu 
określa znawca współczesnych idei betonu - Cyrille Simonnet - jako stan materii bez poczq̨tkowego obrazu ${ }^{1}$, który pośród innych materiałów - dzięki swej „płynnej” naturze - nie ma żadnego wyznaczalnego modelu, formy początkowej, zdolnej do przekazania przez jakieś odwzorowanie. Produkowane jako wynik myśli chemicznej, matematycznej czy estetycznej beton i żelbet są zawsze związane z odniesieniem do stanu, którego określenie i obraz nigdy nie wydają się być ukończone i zamknięte.

Dzięki możliwości swojego przeobrażenia beton wydaje się być zatem „matrycą” idei architektonicznych - jest najbardziej „podatnym na wyobrażenie” materialnym śladem i odciskiem wyrażanych w nim ekspresji formalnych. Jako materia niezwiązana i kompozytowa (mieszanina kruszywa, wody i cementu) jest - w pewnym sensie - synonimem arystotelesowskiej „materii pierwszej”, która przez właściwości („potencjalność”) może być traktowana jako metafizyczny „substrat zmian” architektonicznych. Beton prymarnie jest tylko nazwą, wielkością, cechą, która ma zdolność przyjmowania kształtu, jest ciałem uniwersalnym. W sensie gotowej substancji, zastygłej w formie, beton staje się „materią drugą" - materiałem, którego właściwości fizyczne stają się budulcem dla wyznaczonej przez twórcę idei/ metafory. Obie kategorie materii stanowią właściwy przedmiot pracy architekta jako rzecz fizykalnie traktowana, jako „substrat" - podłoże dla wszelakich form architektonicznych, ale także jako „abstrakt”, ukazujący jego cechy i naddane przez architekta znaczenia.

W obu stanach skupienia beton „uzyskuje przywilej” bycia metaforą - przeniesieniem cech tworzących nowe i niepowtarzalne znaczenia architektury. Beton wraz ze swoją „nieuchwytną" naturą zdaje się być bardziej żywiołem niż ciałem czy substancją, w takim sensie, w jakim nazywamy ogień, wodę, powietrze i ziemię. Aspekt podkreślający właściwości betonu dostrzegał Louis Kahn, apelując do rozwagi i wyczucia twórców: „Musicie poznać naturę betonu, to, czym naprawdę chce być. Beton chce być granitem, ale nigdy do końca się nim nie stanie. Pręty zbrojeniowe grają rolę sekretnego twórcy, który sprawia, że ten tzw. lany kamień jawi się jako wspaniały wytwór ludzkiego umysłu. [...] Czym chce być beton: wytworem umysłu"2.

Architektura budowana z betonu jest zatem przykładem kreacji, w której twórca podejmuje decyzje ideowe i formalne na podstawie wybranej a priori materii dla budowli. Jest wręcz dyscypliną pełnego podporządkowania betonowi wszystkiego, co twórca chce wyrazić w formie budynku. Podobnie jak rzeźbiarz, którego praca uzależniona jest całkowicie od materii, architekt wyszukuje najpierw tworzywo, a potem decyduje o kształcie w nim „ukrytym". Beton, w odróżnieniu do stali, cegły czy drewna, jest do tej roli idealnie predestynowany, ponieważ sam jest materią in statu nascendi, nabierającą sensu i zmieniającą znaczenia wraz ze zmianą kontekstu ideowego czy formalnego. Owa „efektywność” estetyczna betonu jest cechą przyporządkowaną woli twórcy ukazania tak pewnych treści ogólnych, w których beton odgrywa rolę podbudowy, jak i tych bardziej szczegółowych rozwiązań, gdzie beton oddaje istotę jego wykorzystania. 


\section{DETAL}

Od stu lat betonowy detal jest miejscem, w którym twórcy architektury betonowej próbują odnaleźć swoistą „naturę” betonowych budowli. Niezależnie, czy stoimy przed dziełem modernizmu, postmodernizmu czy dekonstruktywizmu - architektoniczny szczegół wydaje się posiadać tę samą moc, którą autor zawarł w całej strukturze budowli. W poszukiwaniu wzorców formalnych architektury docieramy do momentu, kiedy zaczynamy rozumieć, że także betonowy detal ma swoje modelowe odniesienia, ukryte w pełni świadomym i zdeterminowanym działaniu architekta. Tę analogiczną zasadę widać w „surowych betonowych" budowlach Augusta Perreta i Le Corbusiera, w dekoracyjnych stylistykach Carla Scarpy czy w detalu „odnajdującym ład” Louisa Kahna. Każdy z twórców nowoczesności stworzył odrębne podwaliny do rozumienia oraz logiki detalu architektonicznego - niezależnie, czy stanowi on autonomiczną część architektury, czy jest traktowany jako jej dopełnienie.

Choć aspiracje stylistyczne są różne, to ta sama wydaje się jasność i szczerość ideowych rozważań twórców. Dla Perreta było nim skierowanie uwagi wstecz, na klasycyzm gotyckiego ideału katedry. Dla Le Corbusiera wizja idealności detalu była jednoczesnym naciskiem myślenia od ogółu do szczegółu i od szczegółu do ogółu i oddającym sens kontrolowania równowagi nad tymi dwoma biegunami architektury. Po latach technicznych rozwiązań corbusierowski „detal narracyjny” [detail parlant], inspirowany wątkiem orfickim (najczęściej damsko-męskim), zostaje przeobrażony w zasadę obrazu architektury ukrytego w szczególe, reprodukującym jedność idei i materiału. Dla Carla Scarpy detal jest kategorią architektury biorącej początek od piękna indywidualnego - „pięknego szczegółu” lub „pięknych części”, które przez połączenie w całość zamienia się w piękno idealne.

Według Louisa Kahna detal jest wręcz początkiem każdej architektury - „gdy się ma do czynienia z fragmentem, niezależnie od wielkości, struktury, światła, reaguje się na jego charakter, jego atmosferę duchową, zauważamy, że wszystko, co człowiek proponuje i realizuje, staje się pojedynczym bytem"3. Podziela tę opinię Kenneth Frampton, dla którego detal jest traktowany jako istotny element „połączenia” [joint], nadającym decydujące, narracyjne znaczenie każdej strukturze przez widoczność i jakość tych połączeń: „To w punkcie łączenia, płodnym detalu, ma miejsce konstruowanie, jak i interpretowanie architektury. [...] Oryginalny indoeuropejski rdzeń słowa sztuka (art) oznacza łączenie”" ${ }^{\prime 4}$ Formuła przejścia i połq̨czenia nie jest tylko odzwierciedleniem systemu budowli, lecz także „oznacza” punkty węzłowe dla całości struktury. Skutkiem tego rodzaju myślenia o znaczeniu tektoniki budowli są rozważania określające kiedyś ornament, a dziś - detal architektoniczny. 
Współcześnie tropami apologetów nowoczesności podążają ci polscy architekci, którym doskonałość architektury kojarzy się nie tylko z zasadami architektury XX wieku, ale także z tym, co definiujemy jako poszukiwanie estetyki w stosownej ekspresji form. Dla jednych beton, dzięki swym właściwościom, otrzymuje miano rzeczy przynależnej do świata spoza architektury - rzeczy zgodnej z tezą Le Corbusiera, że „,architektura jest problemem plastycznym". Owa poetycka przemiana betonu w każde wyobrażenie architekta staje się nieodłącznym atrybutem ekspresyjnej metaforyki. Dla innych architektura jest okazją ukazania przez budulec porządku - prostego i szczerego w przekazie - zgodnego z symbolem „otwartej dłoni” Le Corbusiera. To dla nich beton staje się przede wszystkim narzędziem tworzącym racjonalną przestrzeń, wspomaganą ograniczeniem środków wyrazu.

Czy beton w architekturze wybudowanej w ostatnim czasie na terenie Polski posiada te dwa różne oblicza? Wydaje się, że obie stylistyki architektury betonowej są wyraziste i ukazują sens twórczych poszukiwań - tworzą na swój sposób spójny świat, wypełniony przekonaniem architektów o idealności zastosowanego budulca. Także oba sposoby prezentacji - metaforyczny i racjonalny - traktować należy nie jako przeciwieństwo, lecz raczej jako konkurencja form współczesnych. Odnaleziony w tym zbiorze detal architektury betonowej tworzy nowe typologie, podkreślając własny, niepowtarzalny styl.

\section{POSZUKIWANIE EKSPRESJI - METAFORY W BETONIE}

W architekturze obraz rzeczywistości zawsze wydawał się być „niewystarczający” i być może dlatego zawsze istniał powód do tworzenia metaforycznej architektury, mającej funkcje „kompensacyjne”. Za jednym razem jest nim przekonanie o poetyckiej potrzebie wykorzystania mocy przenośni do spotęgowania formalnej ekspresji budynku. W innym przypadku świadomość istnienia architektury jako sztuki odbieranej publicznie daje powód do wprowadzenia jej w świat nietypowego komunikowania się z widzem przez język fikcji - rzeczy podkreślających swobodę wypowiedzi wobec otaczającej unormowanej rzeczywistości. Tak rozumiana poetycko architektura jako sztuka tworzenia „nowego” jest obrazem metaforycznym, zyskującym własną, indywidualną wagę i odpowiedni status znaczeniowy.

Ciągłe podkreślanie izotropowych cech betonu jest specyfiką praktyki Fernando Menisa. Centrum Kulturalno-Kongresowe Jordanki w Toruniu (2015) ${ }^{5}$ to przykład poszukiwania tych kamiennych cech betonu, które byłyby stosowne do reinterpretacji architektury jako rzeczy opartej na archetypie groty (także grobu, schronu, bunkra, bastionu), dającej pierwsze schronienie. Grota to zasada tworzenia przestrzeni stereotomicznej - wydrążonej masy w materii, związanej z ziemią lub skałą - wprowadza nas w świat masy, mroku, pustki i tajemnicy, odgrodzenia od świata zewnętrznego, jest stabilnością i związaniem z bazą. Menis 
hołduje surowym architektonicznym formom, nawiązującym do kształtów natury. Najczęściej wykorzystuje beton, drewno, kamień, zestawiając ich kolory i faktury oraz wydobywając walory ich struktury grą światła i cienia.

W monumentalnej toruńskiej budowli detal osiąga znaczenie szczególnej identyfikacji. Od zewnątrz bryła wykonana została z jasnego betonu z widocznym rysunkiem drewnianych szalunków, podzielonych na ukośnie pola wprowadzające poczucie dynamizmu, podkreślającego mocną, organiczną formę. W nieregularnych bryłach zaprojektowano wydrążenia, nawisy i półki przyciągające uwagę intensywnym kolorem. Picado, czyli beton wymieszany z cegłą, pojawia się nieprzypadkowo i jest świadomym nawiązaniem do historycznej ceglanej zabudowy Torunia ${ }^{6}$. Ten ciekawy konglomerat betonu i kruszywa podkreśla dychotomię między dziedzictwem a nowoczesnością w tym centrum kultury. Ustalonej rzeźbiarskiej powłoce sali koncertowej towarzyszą wnętrza - labiryntowe i płynne w łączeniu w sobie różnych funkcji, które w sposób harmonijny przenikają się i wzajemnie uzupełniają. Beton w Centrum Jordanki spełnia swoją monolityczną reprezentacją sens topofilii - subiektywnego i emocjonalnego odbioru miejsca w mieście i jego materialnego charakteru.

W toruńskiej sali koncertowej picado otrzymuje dodatkowe znaczenie, bo oprócz zaskakujących efektów plastycznych, beton cechuje doskonałe pochłanianie dźwięków. Dzięki zastosowaniu ruchomych sufitów oraz wielu zaawansowanych rozwiązań pikado odznacza się doskonałą akustyką i pełni rolę absorbera podczas koncertów symfonicznych czy inscenizacji operowych. W efekcie wymyślona przez architekta mieszanka nie tylko nadała budowli mimetycznego charakteru w stosunku do historycznego centrum Torunia, lecz otrzymała funkcję litego wygrodzenia przestrzeni od otaczającego centrum zgiełku miasta. Trzy niezależne betonowe wolumeny wyznaczają mrok i ciszę przestrzeni, gdzie prostocie i surowości materiału towarzyszy światło przenikające przez wycięcia porowatych kubatur. Beton wraz z ustalonym przez architekta sposobem doświetlenia jest tym samym nawiązaniem do ścian platońskiej jaskini, w której odbija się „poetyckim cieniem” nierzeczywistość całego realnego świata. Rozbite i rozproszone światło tworzy fantazyjne wzory i figury, których odczytanie uzależnione jest od perspektywy, wiedzy i wrażliwości oglądającego. Zrozumienie tej idei jest uzależnione od kształtu obrazu rzutowanego „na” materię i „w” niej przeobrażonego. A jeżeli to prawda, że „świat zmysłowy jest starszy od świata myślowego" ${ }^{7}$, to zdziwienie wobec materii i oświetlonych przestrzennych kształtów w niej uporządkowanych jest pretekstem do odkrywania architektury Fernando Menisa. Metafora takiej budowli służy temu, aby ujawnić rzeczywistą i fundamentalną podbudowę dla tej części architektury, w której poszukiwanie sensu polega na odnajdywaniu materialnych znaczeń.

Podobną rolę betonu - ważnego dla przeobrażenia koncepcji sali koncertowej w realny obraz architektury - dostrzegamy w nowo powstałej siedzibie Narodowej Orkiestry Symfonicznej Polskiego Radia w Katowicach $(\mathbf{2 0 1 4})^{8}$, zaprojektowanej przez biuro Konior Studio. Sala koncertowa została potraktowana jako monolityczne „naczynie na dźwięki”, będące odwołaniem do rozumienia, czym jest uniwersalny związek formy z materią w sztukach 
przestrzennych. Przykład metafory naczynia, często przywoływany przez krytyków, bardzo dobrze obrazuje właściwe uformowanie we właściwej materii w celu przeniesienia tej lub innej wymyślonej zawartości (treści). Forma, treść oraz materiał powinny tworzyć całość, mają dopełniać się nawzajem. Sposób projektowania i budowy NOSPR odkrywa twórczą zmysłowość, percepcję oraz recepcję formy oraz dostosowania im właściwych materiałów - są one także dowodem na ulubioną przez architekta pochwałę cierpliwości w kreowaniu detalu.

NOSPR to pochwała specyficznego procesu kształtowania budynku, w którym systematyczne budowanie z betonu oraz cegły i towarzysząca temu wrażliwość na światło, dotyk, słuch, wynika z przekonania, że architektura, począwszy od pierwszego szkicu, jest pewną „powolnością” działania, rzemieślniczym dochodzeniem do doskonałości, ale także - na samym końcu - odczuwaniem niematerialnej aury stworzonej z materialnych obiektów. Jest w tym postępowaniu pewien ślad procesu, który można odnaleźć w stwierdzeniu Louisa Kahna, że budowla musi zaczynać się od niemierzalności, aby przez realny projekt i budo-

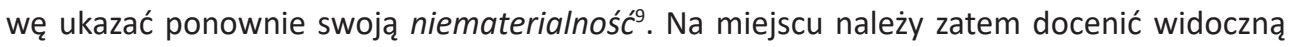
dbałość o jakość każdego z elementów - niezależnie, czy jest to faktura wiszącego nad foyer antracytowego nawisu z betonu ze śladami po deskowaniu, misternie odciśniętych w betonie reliefów na ścianach głównej sali koncertowej czy elewacyjnej cegły wypalanej ręcznie. Jednocześnie architekt potrafi uczynić z tej samej betonowej materii formę podkreślającą ciężar i gęstość „lanego kamienia”, jak i podkreślić jego plastyczne i płynne możliwości przestrzeń przeobraża się z masywnej i nieprzenikliwej sali koncertowej w wyrafinowaną grę betonowych drapierii ściennych. Każdy z detali jest dopełnieniem formy w taki sposób, aby stworzyć wrażenie Gesamtkunstwerk, w którym formę powinniśmy rozpatrywać w całej jej pełni i we wszystkich aspektach jako strukturę przestrzeni i materii, niezależnie od tego, czy będzie się przejawiała w równowadze brył, czy w przemienności światła i cienia.

Poszukiwanie autorskiej „,wersji architektury” przez Tomasza Koniora jest także nadawaniem rangi i wartości obiektu, które powinny przywracać tradycyjne kryteria oceny przestrzeni architektonicznej pasującej do cech rodzimego kontekstu urbanistycznego. Dla śląskiego twórcy tak samo ważne jest rozumienie betonowej materii, jak i determinacja w podjęciu ryzyka przeobrażenia „rzeczy zwykłej” w „rzecz unikalną”.

Interesującym wzorcem, ukazującym związek pomiedzy fizjonomią miasta a kształtem współczesnej betonowej architektury, jest oddane do użytku w 2017 roku Muzeum II Wojny Światowej w Gdańsku autorstwa gdyńskiego Studia Kwadrat ${ }^{10}$. Charakterystyczna czerwona struktura wraz z dominantą 40-metrowej wieży, wznoszącej się na nabrzeżu kanału Raduni, jest nie tylko symbolem miasta - zawiera w sobie nie tylko określone konotacje z sylwetą gdańskiej starówki, lecz także określa pewien zakres porównań. W swoim otwartym na interpretacje kształcie muzeum kontynuuje tradycję tworzenia współczesnych atektonicznych form, dla których celem nadrzędnym jest to, że architektura ma zawsze coś wyrażać, a nie tylko przedstawiać. Ekspresjonistyczny projekt gdańskiego monumentu (jak każdy doniosły w życiu społeczeństw pomnik) odwołuje się do określonych wartości historycznych 
i politycznych bez wikłania się w rozstrzygnięcie typu symbolicznego. Zdekomponowana forma wraz z jej wyrafinowaną geometrią wydaje się być wielowątkowym manifestem podjęcia dyskusji nad wydarzeniami II wojny światowej. Ma być, jak chcą autorzy, „uniwersalnym znakiem”, współczesną dominantą, lecz nade wszystko, jest hołdem dla udanej próby przełożenia stabilności materii na „energię" formy. Sama bryła w formie pochylonego graniastosłupa może nasuwać skojarzenia z pociskiem lub uszkodzonym podczas działań zbrojnych budynkiem. Abstrakcyjna forma nie imituje żadnego znanego kształtu, dzięki czemu zamiast prostych odwzorowań tworzy niepokojącą aurę miejsca. Jedni uważają, że jest to tonący okręt, inni porównują bryłę do walącego się budynku, jeszcze inni do rakiety wbitej w ziemię, zapory, przeszkody lub znicza.

Główne tworzywo struktury budynku - beton monolityczny - jest niewidoczny dla obserwatora. Przykryty nieregularnie ułożoną okładziną z czerwonego torkretu i szkła elewacyjnego odpowiada jednak za konsekwentne budowanie „rozchwianej” przestrzeni, której spójność materiałowa pozwala na odczytanie wielowątkowego kształtu i zrozumienie jednej nadrzędnej przestrzennej logiki. We wnętrzach homogeniczność czerwonych płaszczyzn zostaje zamieniona na jednorodny surowy monolit, który - uzupełniony estetyką antracytowych paneli, eksponowanych instalacji oraz prostych drewnianych mebli - oddaje wyraz specyficznego znaczenia typologii „wojennych” monumentów - schronów, bunkrów, redut. Beton, tworząc całość, ogłasza ekscentryczność budowli-rzeźby oraz bezkompromisowe podejścia autorów do formy - wartość funkcjonalna wydaje się być drugoplanowa.

Swoje teoretyczne odniesienia posiada Aerotunel w Morach pod Warszawą (2014) autorstwa Biura Projektów Lewicki Łatak. Ten nietypowy w kształcie obiekt wieżowy służy nauce skoków spadochronowych i przyjemności ciągłego oderwania od ziemi. Jak twierdzą autorzy, w budowaniu kształtu obiektu pomógł nietypowy pretekst - torba sklepowa, która napełniona powietrzem tworzy kształt w sposób nieregularny i nieprzewidywalny. Torba, latawiec, rękaw, papierowy balon są formami, które zawsze nam się kojarzą z pierwszymi próbami oderwania od powierzchni terenu, z trudem unoszenia i przeciwdziałania grawitacji. Specjalnym problemem w obiekcie, który miał ambicję pokazania zmagań między siłą wiatru i grawitacją, był wybór materiału. Początkowo myślano o użyciu tkaniny technicznej, jednak względy użytkowe, akustyczne i ekonomiczne spowodowały wybór żelbetu, który pozwolił na wprowadzenie dodatkowych funkcji i także, dzięki swojej masie, dał stabilną strugę powietrza, zapewniającego optymalne warunki użytkowania (w pełni kontrolowanego unoszenia i opadania ludzi). Ta ekspresyjna forma (do złudzenia przypominająca obsewatorium Einsteina w Poczdamie Ericha Mendelsohna z 1921 r.) posiada cechy ciekawej dekonstrukcji, dającej pojęcie o tym, że dla współczesnego architekta powodem tworzenia jest nie tyle efektywność funkcji, ile koncept wspomagany wyobraźnią, której celem jest znalezienie najbardziej oryginalnego kształtu budowli w wybranym tworzywie. Świat architektury dynamicznej i radykalnie zdekomponowanej mówią nam także o tym, że świat tych najbardziej niezależnych stylistyk nie może obyć się bez użycia betonu, ponieważ nawet najbardziej 
krańcowa niezależność formy zawsze zakłada pewną odpowiednią materię tworzenia, w której ta forma ma się ujawnić. W Aerotunelu naturalnie odlany beton w szalunkach systemowych otrzymuje znaczenie dynamicznego budulca, wspierającego sens „zatrzymanego w jednej pozie" kształtu i tworzącego jak w kalejdoskopie grę światła, cienia, asymetrii oraz niezaprzeczalnej inwencji twórców tej architektury.

Specyficznego podejścia do technologii betonu wymagała realizacja siedziby Muzeum Lotnictwa Polskiego w Krakowie (2010) ${ }^{12}$ autorstwa zespołu Pysall. Ruge Architekten oraz Bartłomieja Kisielewskiego. Ten ekspozycyjny obiekt zwraca uwagę swoim przemyślanym rozplanowaniem architektury, wyraźnie kojarzonej z funkcją muzealną i jednoczesnym odzwierciedleniem w formie prezentowanych eksponatów. Bazą dla kształtu muzeum jest pewna ciekawa modyfikacja modułu podstawowego, opartego na wyciętej i złożonej (na sposób origami) kwadratowej kartce papieru, przypominającej w rozplanowaniu trójkątne śmigło. $\mathrm{Na}$ betonowej platformie masywna cementowa giętkość i wszechobecna „supremacja” betonowych płaszczyzn odtwarza pewien sens w odczytywaniu formy dla funkcji. Aspekt swobody kompozycji muzeum w Krakowie wydaje się być kontynuacją tego rodzaju myślenia, które kiedyś w dziełach Oscara Niemeyera i Eero Saarinena, a dzisiaj w formach Franka Gehrego i Zahy Hadid manifestuje sens architektonicznej rzeźby do eksponowania innych rzeźb/eksponatów; stworzenie dzieła sztuki dla innych dzieł sztuki. Dzięki nim wiemy, że linia krzywa, wygięta płaszczyzna, łukowaty podciąg to naturalny kształt architektury, a walory estetyczne budynków mogą być wyrażone jedynie przez samoistne elementy konstrukcyjne.

Tej wyszukanej metaforze odrzucającej kąt prosty oraz jej nieskrępowanej geometrii towarzyszy dostrzegalna dbałość o każdy element wykonany z betonu, stali i szkła. Krzywizny zewnętrznej, 120-centymetrowej skorupy, wykonanej z barwionego w masie antracytowego betonu, wymagały specjalnych rozwiązań i przygotowania wyprofilowanych szalunków traconych, stworzonych na stalowej podkonstrukcji. Powtarzalny ślad odciśnietych blatów szalunkowych, dopracowanie narożników, rozwiązanie okien, spójnie wykonane wnętrza sal muzealnych i przestrzeni administracyjnych czy finalne polerowanie fasad świadczą o tym, że detal oderwany od trwałej podstawy modernistycznego mitu staje się ważnym elementem wyzwolonym z byle jakości - zależy od wizji, wrażliwości, wiedzy tych, którzy stwarzają go zawsze na nowo.

Do innej kategorii zdekonstruowanych betonowych metafor należy Muzeum Martyrologii Wsi Polskiej w Michniowie, zaprojektowane przez Nizio Design International (2017) ${ }^{13}$. Budynek muzeum ma przypominać o tragicznych wydarzeniach pacyfikacji wsi przez hitlerowskie oddziały w lipcu 1943 roku. Architektura monumentu w Michniowie związana jest nieodłącznie z rozpoznawalnymi archetypami: domu, drogi, bramy, granicy, ogrodu, drzewa. Część z tych elementów jest powtarzalna i rozpoznawalna, inne tworzą świat podporządkowany materializacji idei przez utrwalenie w budulcu. Wszystkie razem tworzą obraz wzorca, w którym światło, woda, budulec architektury wydają się tak samo ważne jak jego specyficzne formalne ukształtowanie. 
Projekt realizacyjny muzeum jest konsekwentną kontynuacją koncepcji konkursowej, zakładającej ukazanie rozpadu i deformacji tradycyjnie pojmowanego domu wiejskiego. Liniowa, monumentalna figura w swoim rozbiciu i dekompozycji podkreśla jedność narracji historycznej i architektonicznej, w której sensem głównym jest monolit betonu. Droga, którą należy odbyć wśród strukturalnych, cementowych ścian opowiada nie tylko o wydarzeniach z tragicznej przeszłości, lecz także buduje dodatkową narrację. Począwszy od pełnej figury „domu” (służącej za kaplicę) przez poszczególne, coraz bardziej rozbite segmenty ram ekspozycji, dochodzimy do miejsca ustalającego finalny zanik i destrukcję. Istotne na tej symbolicznej drodze jest światło przenikające przez szczeliny okien i świetików w 80-centymetrowej zewnętrznej ścianie. Pasy świetlne tworzą wraz z wewnętrznymi fasadami konsekwentną kompozycję linii, cięć i promieni, właściwą dla obiektu, który powinien przemieniać profanum materii na sacrum przestrzeni upamiętniającej tragedię mieszkańców Michniowa.

Symbolika „nieobecności” wśród zastygłej w betonie „nagiej” i bezosobowej formie staje się podstawowym obrazem pamięci po rzeczy już nieistniejącej. Autorzy, wykorzystując esencjonalną, dobrze zrozumiałą w kulturze metaforę domu, tworzą zarazem uniwersalny znak rozpadu, śmierci i przemijania, oparty na dualizmie tego, co zarazem obecne i nieobecne. Betonowe „domy” w Michniowie wydają się być wizualizacją czegoś na kształt „maski pośmiertnej architektury".

\section{POSZUKIWANIE DOSKONAŁOŚCI - BETON RACJONALNY}

Pewność, z jaką sto lat temu Adolf Loos mówił o panującym „barbarzyńskim splendorze”, zdradzała głęboko ugruntowane przeświadczenie, że architekci nowocześni mają także inne standardy doskonałości. Istnieje w historii sztuki Zachodu odmienny estetyczny ideał - racjonalnej powściągliwości, który jednak wiąże się nierozerwalnie z tradycją klasyczną. Ernst Gombrich twierdził, że przemyślane odrzucenie nadmiaru ornamentu było zawsze oznaką wpływów klasycznych. Tam, gdzie to staje się przedmiotem dumy, jak to bywało w czasach włoskiego renesansu i XVIII-wiecznego neoklasycyzmu, zwrócenie uwagi bardziej na formę niż dekorację staje się znakiem świadomej siebie artystycznej cnoty ${ }^{14}$. Tak pojęty racjonalizm daje również jednoznaczną odpowiedź na pytanie o udział i sens detalu architektonicznego w tworzeniu znaczeń architektury elementarnej. Według tej reguły architektura ma być samoopisująca i introwertyczna, a więc język, jakim się posługuje autor budowli, ma być medium rygorystycznie wyodrębnionym z logiki, prostoty, geometrii i liczb - po prostu techniki. Racjonalna architektura bez wyodrębnionego ze struktury detalu ma wskazywać na rozróżnienie pomiędzy tym, co jest „w głąb”, a tym, co jest „na zewnątrz”. Architektura „poza stylem” - oto główna funkcja formalna architektów spod znaku poszukiwania piękna obiektywnego. Dla tych architektów, którzy powtarzają, że „architekt nic nie wymyśla, jedynie przeobraża rzeczywistość", szczerość materii osiąga ten walor, który eliminuje to, co niepotrzebne, ale także poszukuje sensu w tym, co nazywamy kontynuacją. 
„Racjonalny beton” jako oczywista część krajobrazu współczesności stał się przez swą naturalność, neutralność i syntetyczność tworzywem idealnym dla twórców spod znaku redukcji formalnej - jest materią wytworu anonimowej techniki, produkcji, rzeczy niemających utrwalonych odwołań znaczeniowych i estetycznych. Beton jako materia pasująca do ograniczenia stylowego, wyzwalającego emocję w ascezie kształtu i budulca, odnajduje swoje źródło w estetyce, która przez upowszechnienie percepcji staje się bezosobowa i pozbawiona referencji. Jako materiał nieimitujqcy, nieepatujqcy i nieobecny jest doskonałym tworem dla pozbawienia sztuki możliwości dedukcji nad sposobem tworzenia.

Nieodległy od szkoły redukcji formalnej jest dom własny Roberta Koniecznego w Brennej w Beskidzie Śląskim, zrealizowany w 2015 roku. Budynek ukazuje nam kolejny sens znaczenia formy "domu”, którego wyraz architektoniczny ograniczony jest do esencji geometrycznej archetypu (architekt nazywa go „Arką”). Betonowy obiekt, zlokalizowany na stoku, choć powstał jako wynik dopasowania do warunków geologicznych i prawnych, jest wyjątkowy w swoim podejściu do formy zawartej w betonie. W architekturze Arki ujednolicenie i uproszczenie kształtu oraz materii staje się celem, dla którego redukcja jest rozumiana jako funkcja najprostszego rozwiązania. Dom posiada dach dwuspadowy, analogiczną dla dachu podobudowę, cztery ściany, panoramiczne okno, wejście. Wszystko spaja czysta szarość monolitycznego betonu oraz starannie wykonanego, niezakłóconego kominami dachu. Lapidarność domu przypomina projekt kaplicy w Cazis (1993) Christiana Kereza, gdzie nieskomplikowana retoryka architektury dochodzi do momentu, kiedy odwołanie do środków minimalistycznych oznacza kalkulację: z ilu i jakich elementów składa się obiekt architektury. Wydaje się wręcz, że dla Koniecznego-purysty podejście "fizyczne" do dzieła jest nadrzędne w stosunku do idei samego dzieła. Architekt sprowadza do minimum jego wartość artystyczną, ograniczony kanon form lapidarnych - jak prostokąt, trójkąt, płaszczyzna, krawędź. Twórca świadomie rezygnuje z nadawania walorów strukturom powierzchni - wszystkiego, co może określać niepotrzebną i dodatkową narrację architektury. „Beton neutralny” Koniecznego to proces transpozycji tworzywa idealnego dla „architektury prostoty”, w której przyroda i geometria nie są przede wszystkim pytaniem o treść, lecz raczej o metodę definiowania przestrzeni elementarnej ${ }^{15}$.

Dom wybudowany w Bierkowicach pod Opolem (2015) i zaprojektowany przez zespół DB 2 Iwony Wilczek i Mariusza Tenczyńskiego jest bezkompromisowym oddaniem tego, co tłumaczy widzom, czym jest nowoczesna przestrzeń mieszkalna. Obiekt o powierzchni $452 \mathrm{~m}^{2}$ jest przemyślaną strukturą, odlaną w surowym betonie i uzupełnioną systemowym przeszkleniem otwartym na wewnętrzną część działki. Ta prostopadłościenna bryła odkrywa przed nami swoją podwójną twarz - jej granicą jest monolityczny mur rozgraniczający część wejściową (z betonowym placem jako kontynuacją estetyki elewacji) od części mieszkalnej, której w pełni otwarty plan wraz z organizacją korytarzy i otwarć stanowi niejako kontrapunkt dla litej północno-wschodniej elewacji. Niewyszukany i prosty beton wejściowej przegrody nie ukrywa swojej natury, jego niedoskonałość buduje sens rzeczy najprostszej 
i regularnej, której podstawową funkcją jest wydzielenie architektonicznego boîte à miracle - przestrzeni ciszy, dostatku i prywatności ukrytej za nieprzeniknionym murem. Wejście do środka domu wyznacza drogę wśród nienagannie czystych i przejrzystych kompozycji brył, płaszczyzn materii, okładzin oraz mebli kadrowanych betonowym nawisem. Całość otoczona basenem określa zamkniętą i skończoną kompozycję.

Nowatorstwo tej budowli polega przede wszystkim na konsekwentnej i racjonalnej drodze dochodzenia do kształtu architektury. Dla twórców „odkryć” to znaczy „odnaleźć na nowo”, „na nowo uporządkować” to, co jest ukryte w twórczej podświadomości i co ostatecznie oznacza wyabstrahowanie architektury w stronę czystej i zawsze bogatej w odniesienia euklidesowskiej geometrii. Ów rygor kompozycyjny traktowany jest jako przejaw redukcji formy do jej istoty lub jako tworzenie ideału. Taka „potrzeba kreacji” dla racjonalisty jest także „potrzebą formy", ale takiej, w której dominuje równowaga między najważniejszymi składowymi. Idealizacja formy domu pod Opolem to poszukiwanie wśród wielu możliwości figur tego ciała, które byłoby w stanie „odsłonić duszę” starannej betonowo-szklanej architektury.

Przykładem odkrywania uniwersalnych praw geometrii jest Brama Poznania - Interaktywne Centrum Historii Ostrowa Tumskiego (Ad Artis Architects, 2014) ${ }^{16}$, którego czystość architektury jest najważniejszym czynnikiem utrwalania precyzyjnego i doskonałego myślenia o architekturze jako świecie brył czystych. ICHOT stanęło naprzeciwko poznańskiej katedry, w sąsiedztwie miejsc, w których przed wiekami rodziła się polska państwowość. Na tym bezcennym pod względem historycznym terenie architekci zdecydowali się na surową prostopadłościenną formę, która miała stać się tłem dla zabytków Ostrowa Tumskiego. O istocie i hierarchii tego kontekstu przestrzennego może świadczyć ukośna szczelina, przecinająca betonową kostkę ICHOT - przeszklone „pękniecie” bryły otwiera widok z wnętrza wprost na katedralne wieże.

Jak mówią sami autorzy: „,muzeum powstało z betonu i światła” - lecz również z idealnej geometrii kwadratu. Rzeczywiście, budynek zwraca uwagę niezwykłą prostotą przestrzeni, w której światło betonowej architektury tworzy kształt rzeczy bezinteresownej - artefaktu wypełnionego czystym obrazem monolitu. ICHOT wyraża tym przywiązanie do odległej współczesnym teorii piękna jako systemu relacji Claude'a-Nicolasa Boullée'go, potwierdzającej, że to wzajemne ułożenie mas wobec siebie, ze światłem i cieniami, przekaże wrażenie związane z charakterem budowli. W tym monumencie bez zbiorów (za całą ekspozycję dziedzictwa służą prezentacje multimedialne i edukacyjne) wnętrze budynku jest równie minimalistyczne jak jego zewnętrze. W holu i na korytarzach dominuje czerń, posadzki wykonano z płyt bazaltowych, kasy i punkt informacji obito czarną blachą, czarne są też niektóre ściany. Ta surowa monolityczna przestrzeń ma służyć przede wszystkim zwróceniu uwagi na pobudzającą różne zmysły ekspozycję.

Prosta i subtelna betonowa monumentalność tych rozwiązań może wzbudzać emocje, jednak konsekwentne odczucie geometrii budynku opiera się na przekonaniu, że idea zawarta w budowli potrafi oprzeć się zmianom kulturowo-cywilizacyjnym, a ta wydaje się istotą poszukiwania nowoczesnych znaczeń. Wyjątkowo spójny i konsekwentnie zrealizowany 
projekt pracowni Ad Artis Architects jest dowodem na to, że prosta bryła może być efektowną realizacją ideału przez odciśnięcie wyobrażenia o geometrii w betonie i ustalenie związków pomiędzy jej fizycznością, czystością minimalizmu a merytoryką programu. Konserwatyzm odnoszący się do ponadczasowych wartości architektury w ramach materialnych znaczeń oraz manierystycznej geometrycznej prostoty form może stać się sposobem na poszukiwanie ponadczasowości.

Obrazem racjonalizacji formy oraz bezpretensjonalnego traktowania betonu architektonicznego jest budynek Infinity Dreams (2012) Przemo Łukasika i Łukasza Zagały z zespołu Medusa Group. Ten nieduży obiekt biurowy, zlokalizowany w Gliwicach, stanowi wzorcowy przykład unaoczniający zasadę „niemej formy” - odniesienia do idei ascetycznej architektury, której architekci czerpali z zasad czysto informatycznego i ekonomicznego myślenia. Surowość budynku i nawiązanie jego wystroju do technicznego czy wręcz przemysłowego charakteru posiada pewien walor, polegający na głębokiej świadomości procesu budowania, uznania fizyczności mającej wpływ na końcowy efekt projektowania, na świadomości materiału i technologii. Niepodważalnym paradygmatem dla tego typu architektury jest z pewnością stylistyka szwajcarskich twórców, wywodzących się z Eidgenössische Technische Hochschule (ETH) w Zurychu. Wzorcem tu dają się być dzieła Petera Märkli (Gantenbein House w Grabs, 1995), Luigiego Snozziego (m.in. Guidotti House w Monte Carasso, 1984) czy zespołu Annette Gigon i Mike'a Guyera (podstacja dworca w Zurychu, 1999), które ustanowiły w latach 90. XX wieku podwaliny pod myślenie o związkach idei i materii w betonowej stylistyce racjonalizmu.

W gliwickim budynku służy temu wybór prefabrykatów jako głównego budulca architektury - rzeczy, która staje się pretekstem poszukiwania estetyki „bez właściwości”, ukazującej nonszalancki detal jako efekt styku pomiędzy surową technologią prefabrykowanego betonu, eksponowanymi we wnętrzach instalacjami a gładkością przeszkleń i posadzek. Infinity Dreams w swej programowej i „genetycznej” prostocie oraz schematyczności detalu tworzy własny kod, obejmujący nieskończoną gamę systemów w zaprogramowanym z góry procesie tworzenia architektury. Jak mówią autorzy - to nie są działania awangardowe ani nowoczesne, taki jest po prostu pomysł na współczesność architektury, w której jest miejsce na ukazywanie zasady projektowania oraz pozostawiania śladów po wykorzystanym narzędziu, jakim jest beton.

Retoryka architektury Medusa Group odkrywa kolejną logikę użycia betonu jako budulca etycznego, odkrywającego swoją materialną szczerość i nieskomplikowanie technologiczne. To dzięki Le Corbusierowi ${ }^{17}$ po raz pierwszy uznano, że nieukrywana wadliwość materiału może stać się narzędziem moralnego przesłania architektury. Do dnia dzisiejszego ta świadomie naddana deformacja betonu stała się etycznym narzędziem poznawczym funkcją pokazywania świata takim, jakim jest, ukrywanym w głębi materii przesłaniem, że prawdziwe piękno jest właściwością nie ciał, lecz cnót. Taka architektura może człowiekowi zapewnić poczucie tożsamości, które stanowi jego podstawową potrzebę psychologiczną. W definiowaniu cech betonowej architektury istotne jest podkreślenie nadrzędnych relacji pomiędzy strukturą a jej znaczeniem estetycznym, tworzącym współczesne znaczenie 
terminu decorum, dla którego architekci z Medusa Group wypróbowują różne formy, szukając zawsze plastycznego wyrażenia w fizycznej konstrukcji.

Wpisuje się w ten nurt nowohucki budynek Centrum Rozwoju Com-Com Zone (2008) ${ }^{18}$ autorstwa Wojciecha Obtułowicza. Kompleks sportowo-rekreacyjny to czytelny obraz kompozycyjny, zawierający wymagane programem elementy: tereny boisk, małą architekturę, przestrzenie wodne, kładki, rampy, amfiteatr. Wszystko wytworzone w betonie, co powoduje odbiór projektowanej przestrzeni jako spójnej całości. Ważnym strukturalnie elementem architektonicznym jest wieża widokowa, mierząca 16 metrów wysokości.

Zarówno konstrukcja, jak i wnętrze obiektu wykonane są z monolitu odlewanego bez specjalnej troski o układ blatów szalunkowych i struktury lica, co nadaje im surowy, przemysłowy charakter. Dzieło Obtułowicza nie udaje, że masy zbrojonego betonu to coś więcej niż tylko materiał budowlany. Brutalistyczna budowla jest zatem pozbawiona jakiegokolwiek wykończenia - w ścianach odbija się jedynie podstawowy proces technologiczny. Boiska sportowe, basen pływacki czy plac do skate-board'u przekryto jednolitą, upodobnioną do dachów fabrycznych strukturą stalowych świetlików szedowych (przywołujących na myśl formy dachowe berlińskiego Archiwum Bauhausu Waltera Gropiusa, 1976-1979). Uwierzytelnieniu socjologiczno-estetycznego znaczenia tej architektury służy także ujawnienie układu wnętrz, konstrukcji, jego ciągów komunikacyjnych, instalacji, urządzeń technicznych, rur spustowych. W ten sposób projektant chciał przybliżyć korzystającej z obiektu młodzieży tajniki anatomii budynków i ich technologicznych rozwiązań. Surowy beton pełni tu nie tylko funkcję zewnętrznej skorupy hali, ale jest też głównym materiałem zastosowanym we wnętrzach. Naturalność i autentyczność rozwiązań jest podyktowana ideą architektury jako odwzorowania sposobu życia - jedną z betonowych ścian przeznaczono wręcz do zamalowania przez osoby tworzące graffiti. Taka architektura tworzy dynamiczny obraz budynku pisanego na planie miasta językiem skrótu i rekapitulacji kontekstu, pospiesznie narysowanego znaku w przestrzeni miasta - tworzonego na bieżąco.

Obtułowicz przyznawał, że stworzenie takiego „wyrzeźbionego tylko w betonie” budynku było jego zawsze marzeniem. Swoim projektem chciał udowodnić, że beton nadal doskonale sprawdza się w architekturze i niesłusznie jest przez architektów i odbiorców traktowany jak materiał siermiężny i pospolity. Zdecydowany charakter bryły, mocno zaznaczającej swoją obecność w otoczeniu (tak samo jak przypadku budynku siedziby zarządu firmy Hydrotrest 1999, czy Stadionu Miejskiego TS Wisła - 2010), miał być architektonicznym kontrapunktem dla nieciekawych i pozbawionych wyrazu budynków publicznych, jakie powstawały w okresie transformacji gospodarczej w Polsce. Jak twierdził architekt: „Architektura ma być pozbawiona patosu; ma być prosta i użytkowa"19.

Kwestia dotycząca reguł stosownego budowania jest aspektem od zawsze pojawiającym się w teorii architektury. Mies van der Rohe przypomina nam, że istotą architektury jest zrozumienie, w jaki sposób jeden kamień został położony na drugim. Jeżeli bowiem architektura jawi się jako próba organizacji przestrzeni, to struktura jest organizacją materii do celów stabilności obiektu. Stąd bierze się ważność zastosowanego budulca i rozumienie sposobów 
jego wiązania po to, aby przedłużyć jego trwanie. Dzięki temu architektura wydaje się być nie tylko sztuką form, lecz przede wszystkim sztuką rzeczy strukturalnych. Tak jak w muzyce pojedynczy dźwięk przeniesiony na następną pięciolinię spowoduje zmianę w melodyce, tak samo fuga pomiędzy kamieniami lub szalunkiem może zdefiniować artyzm, precyzję lub ich niedostatek u twórcy w jego dziele.

Twórczość Bolesława Stelmacha jest odwołaniem do słów Miesa van der Rohe - ma mieć podtekst rytualny oraz logikę polegającą na tym, że każda rzecz powinna ożywiać inną przez zestawienia i powtórzenie oraz dogłębne zrozumienie, przeobrażenie oraz oczyszczenie zasad strukturalnych. Taka sytuacja może być potraktowana jako nadanie formom ich „reprezentatywnego" charakteru i jest także początkiem przemianowania techniki w architekturę. Wydaje się jednak, że architekt ogranicza jednak pewien zakres poszukiwań doskonałości: architektura to takie przełożenie, które z zasady dekoracji przechodzi do poszukiwania form odpowiednich.

W poszukiwaniu struktur „odpowiednich” Stelmach szuka walorów architektury stworzonej przez odejmowanie. Jak twierdzi architekt, odejmowanie musi cechować każdy z momentów procesu projektowanego i budowlanego. Każdy z tych etapów musi odnaleźć swoją jakość w koniunkcji redukcji - „są one wtedy tak oczywiste, jak kopanie dołu i usypanie pagórka". Poszukiwanie zredukowanej struktury to droga do wyidealizowanej prostoty geometrii oraz użytych materiałów czy ich końcowej obróbki. Redukcja do trzech, czterech materiałów w budynku daje szansę na silniejszy odbiór poszczególnych przestrzeni.

We wszystkich swych dziełach architekt daje dowód na to, że budując z surowego, „racjonalnego" betonu, można stwarzać bardzo zróżnicowane formy, wywołujące różne nastroje, emocje, wrażenia. Lubelski Park Naukowo-Technologiczny (2014) czy Zana House (2008) wybudowano z najprostszego betonu, który uzupełniony szkłem, stalą i drewnem utrwala rygor myślenia o idei architektury jako rzeczy oddziałującej na zmysły. Różnicując faktury budulca, architekt wykreował sensualne, bardzo wrażeniowe płaszczyzny, dalekie od tradycyjnego rozumienia minimalizmu. Taki sposób potraktowania budulca współgra z maksymalnie uproszczonymi bryłami budynków. Wspólnie tworzą harmonijną, poważną, stonowaną całość, dobrze korespondującą z funkcją obiektu.

Zgodnie z tym założeniem każda z „substancji” budowlanych komponuje ciężar lub lekkość, gładkość lub chropawość, spokój lub rozedrganie. Można odnieść wrażenie, że budynek wraz z detalem ma mieć tylko tyle, ile jest niezbędne do stworzenia budynku doskonałego, z którego nie można niczego odjąć bez utraty jego wartości. Cechą identyfikującą architekturę Stelamacha jest ukazywanie wszelakiej technologii użytej do stworzenia budynku - wszystkie powierzchnie muszą pokazywać technikę wykonania fragmentu czy detalu. Ślad po szalunkach, w których wylano beton, spawy elementów stalowych, widoczne węzły i łączenia śrubowe podkonstrukcji mają przemawiać nie tylko „szczerością” i „uczciwością” traktowania, lecz mają stać się informacją o strukturze i procesie budowania ${ }^{20}$. Każdy detal ma wzmagać poczucie realizmu dzieła i tworzyć wraz ze śladami użytkowania istotę tej architektury - trwanie w czasie poza stylistykami i modami. 

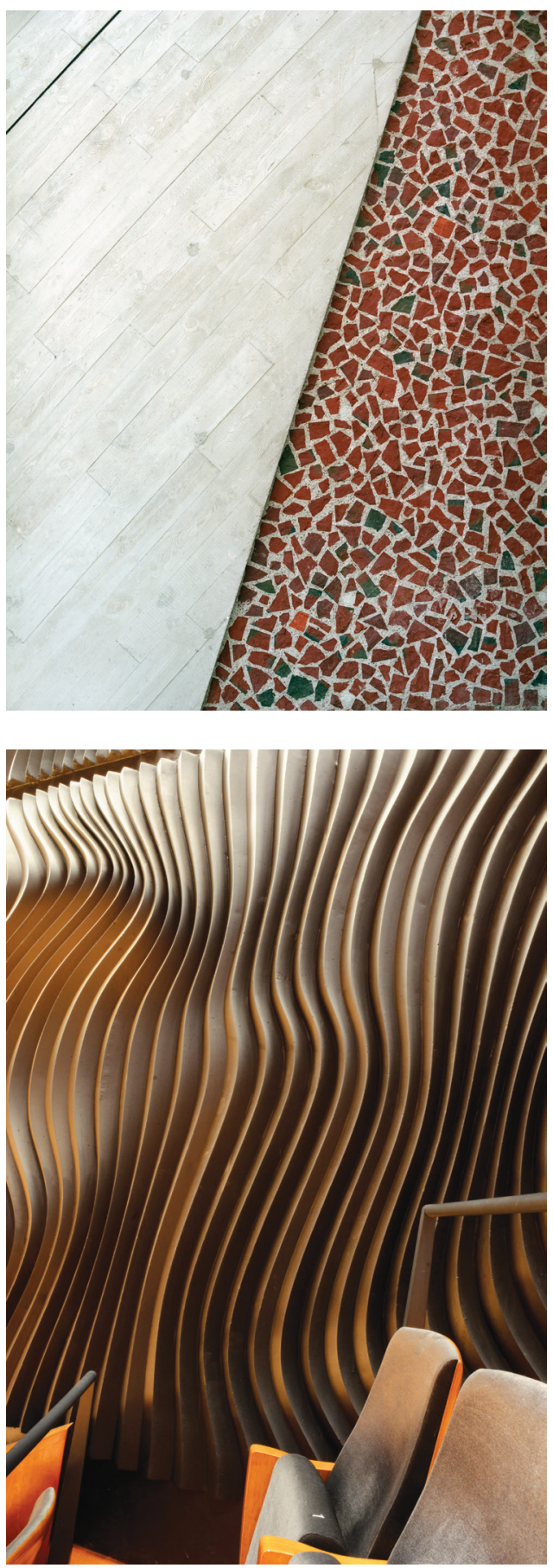

II. 1. F. Menis, Centrum Kulturalno-Kongresowe Jordanki w Toruniu, 2015 


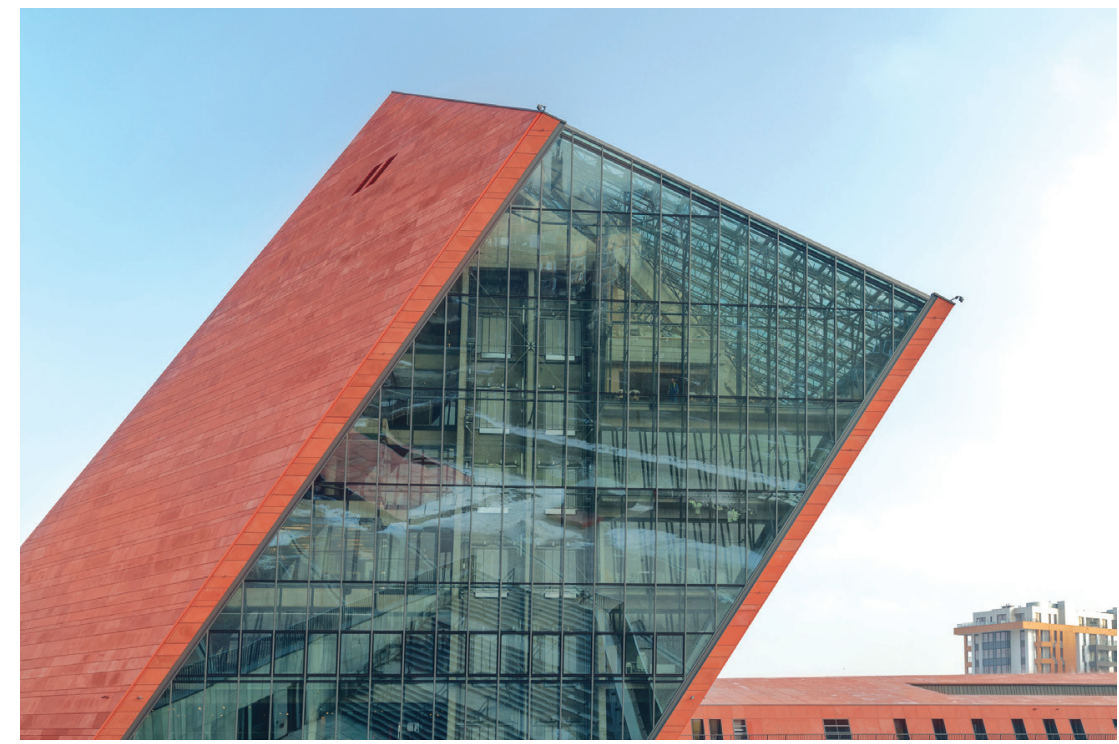

II. 3. Kwadrat Studio, Muzeum II Wojny Światowej w Gdańsku, 2014

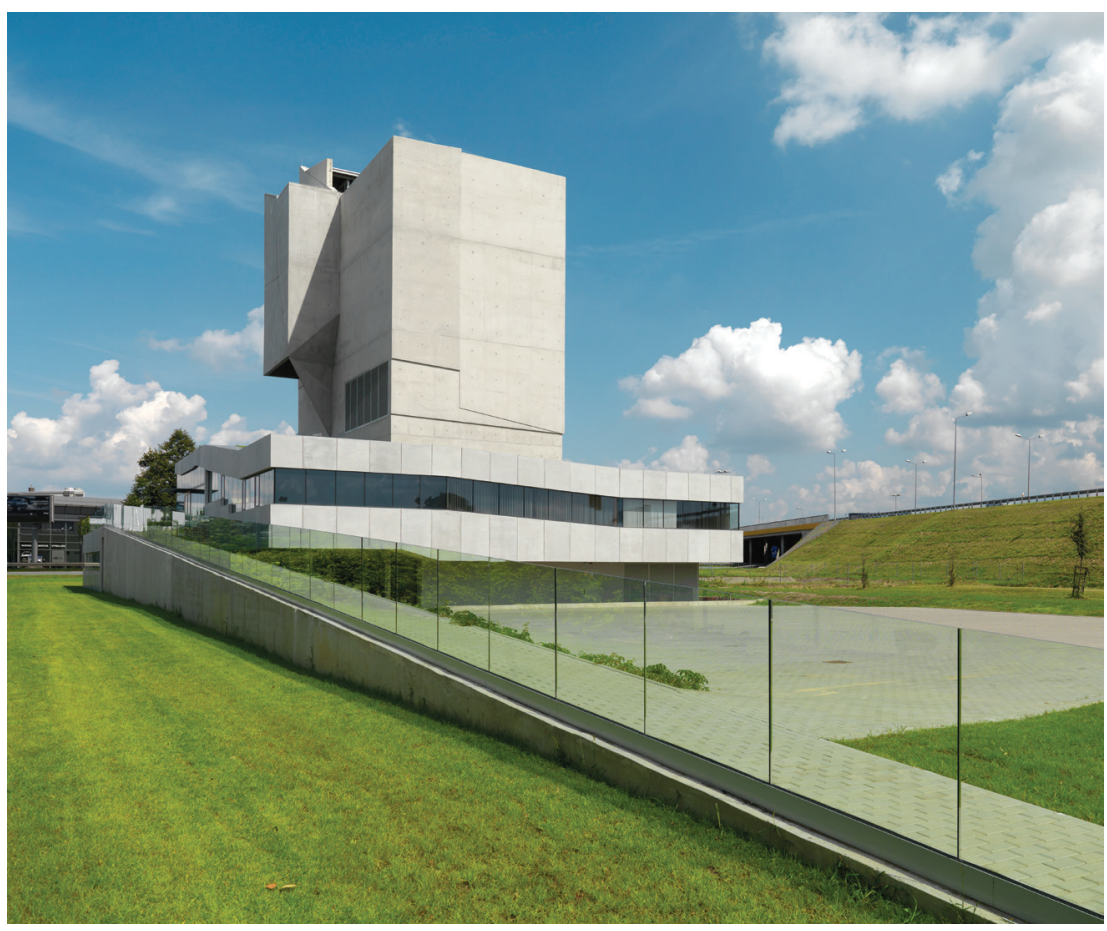

II. 4. Lewicki i Latak Studio, Aerotunel w Morach, 2014 


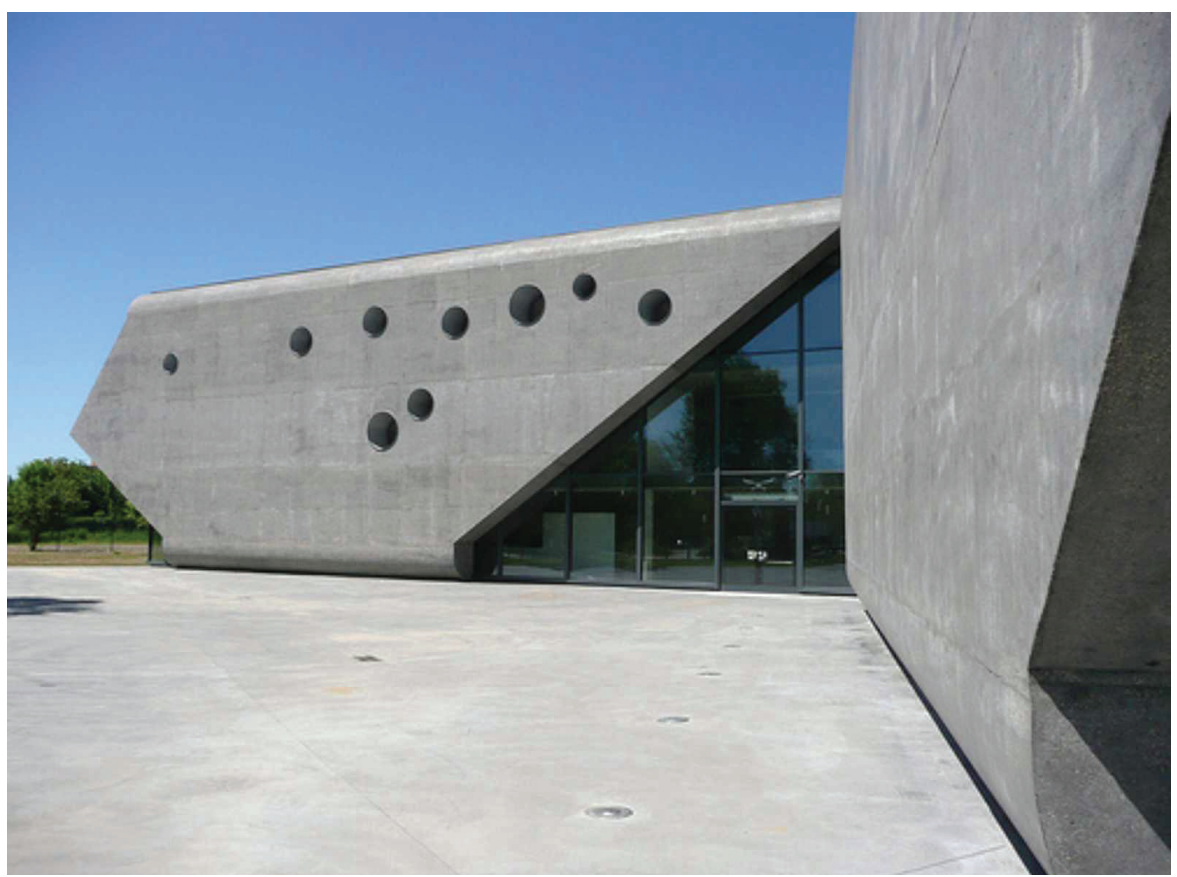

II. 5. Pysall. Ruge Architekten i Bartłomiej Kisielewski, Muzeum Lotnictwa Polskiego w Krakowie, 2010

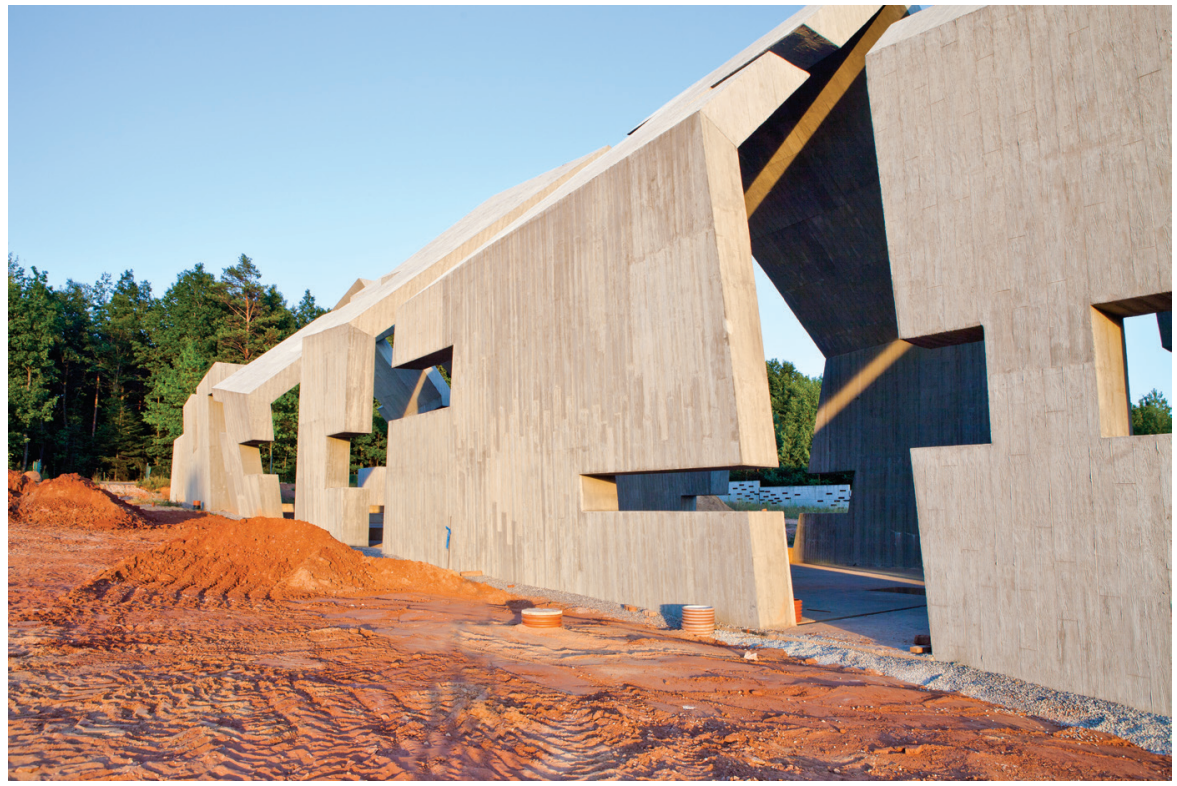

II. 6. Nizio Design, Muzeum Martyrologii Wsi Polskiej w Michniowie, 2017 
II. 7. Robert Konieczny, Promes Studio, The Arc, Brenna, 2015

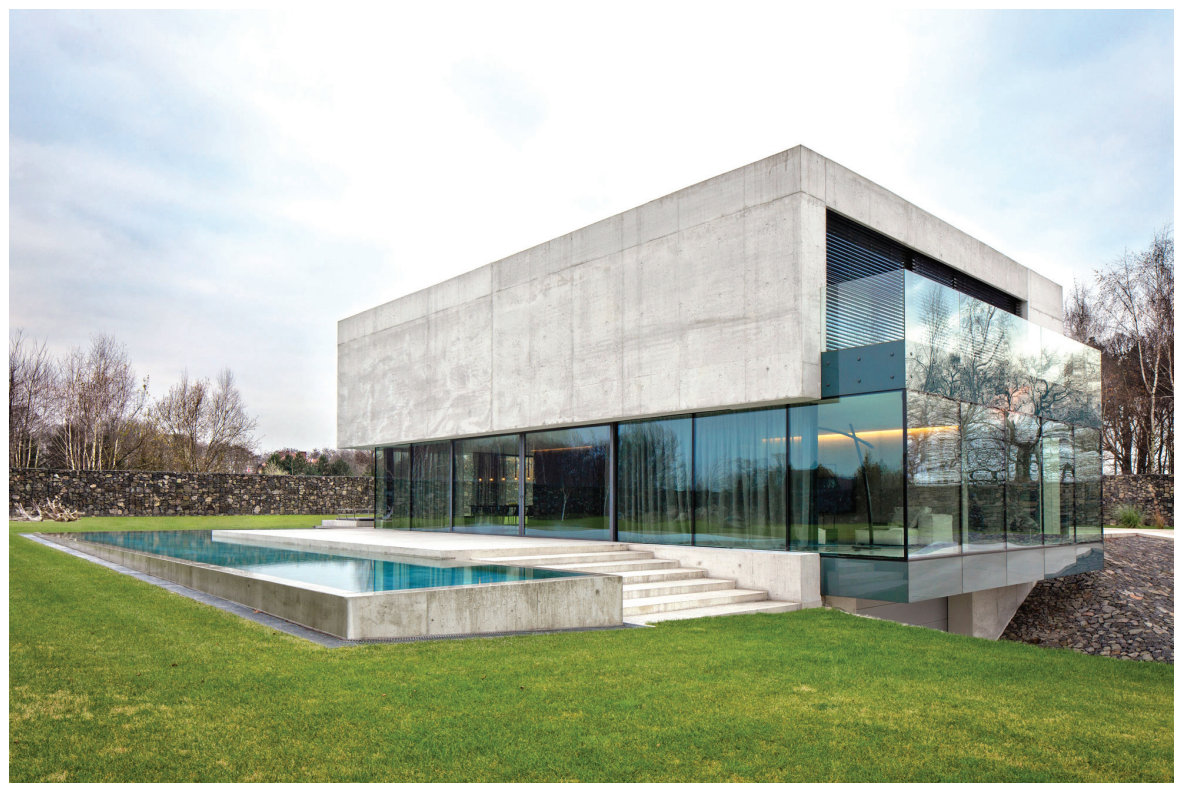

II. 8. Studio DB2, Dom w Bierkowicach, 2015 


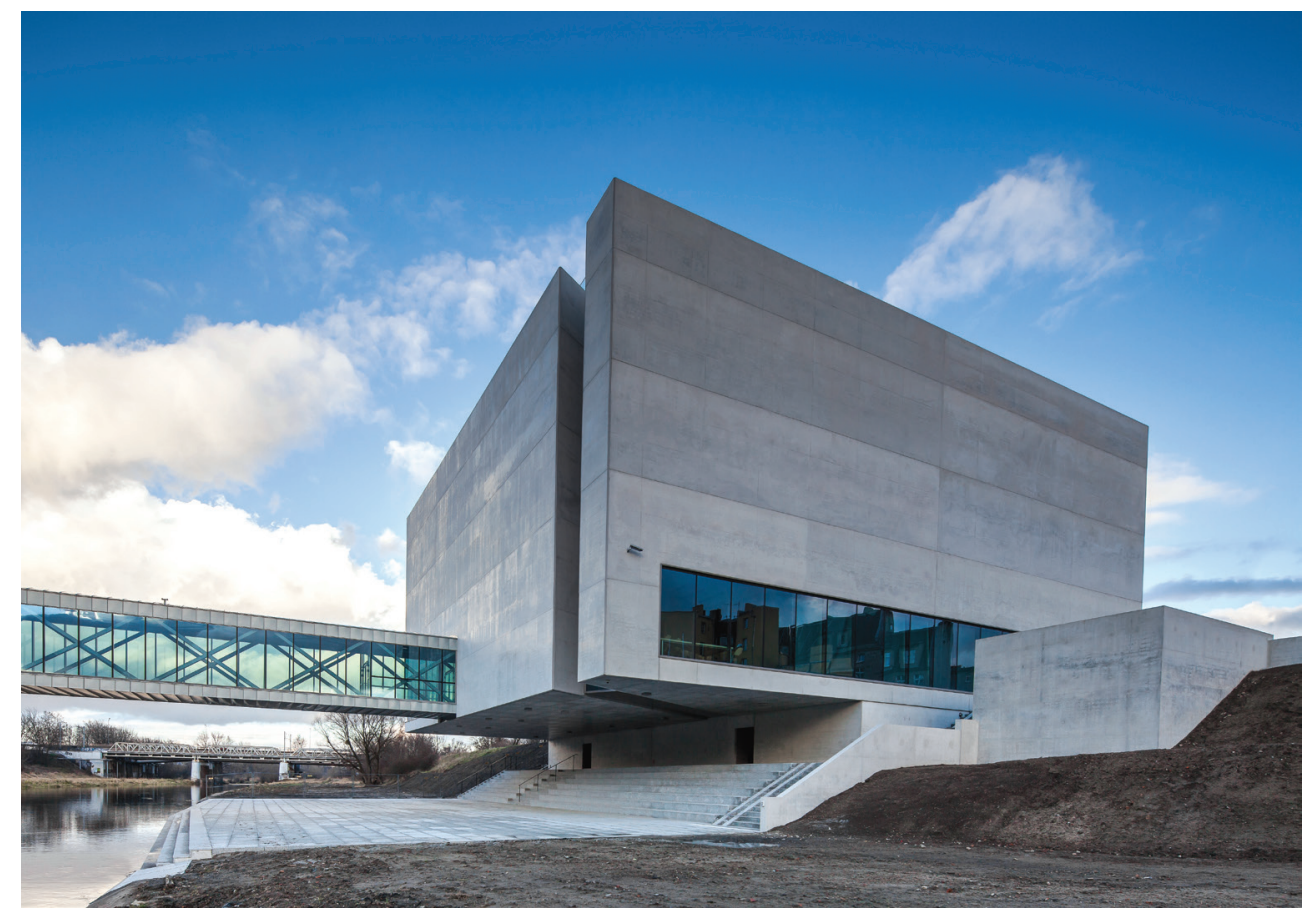

II. 9. AD ARTIS Studio, Brama Poznania - Interaktywne Centrum Historii Ostrowa Tumskiego, Poznań 2014

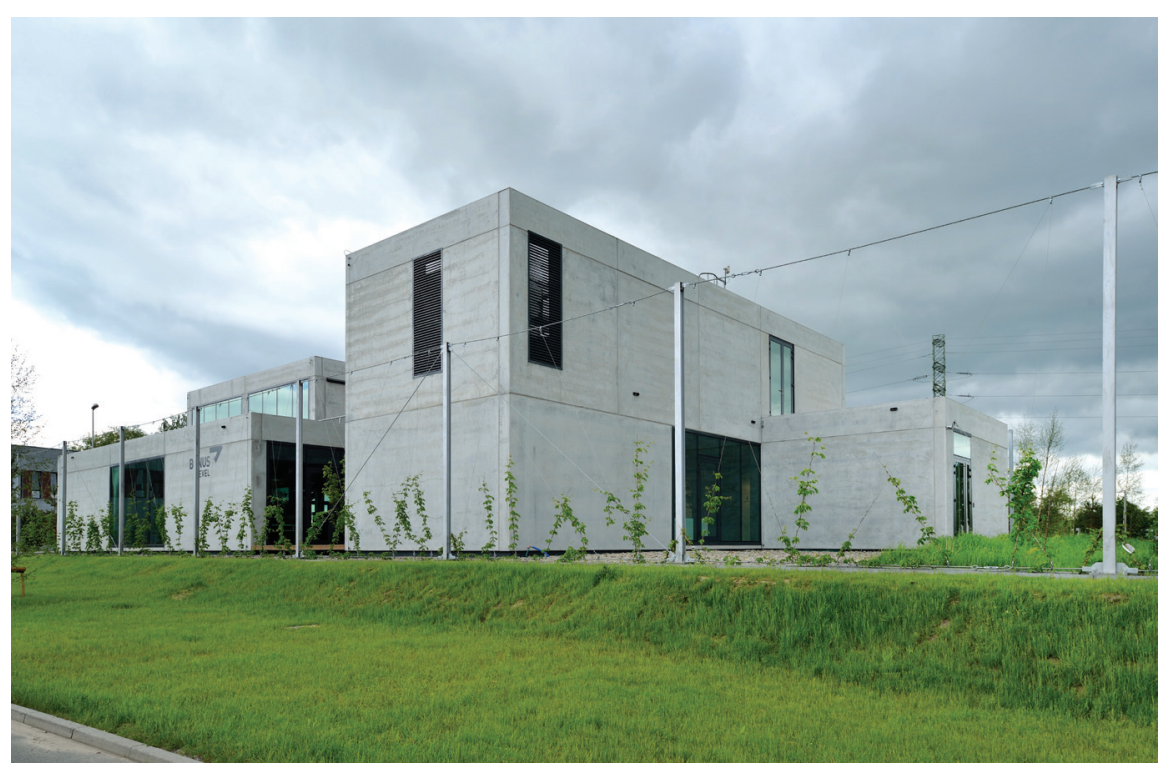

II. 10. Medusa Group, Infinity Dreams, Gliwice 2012 

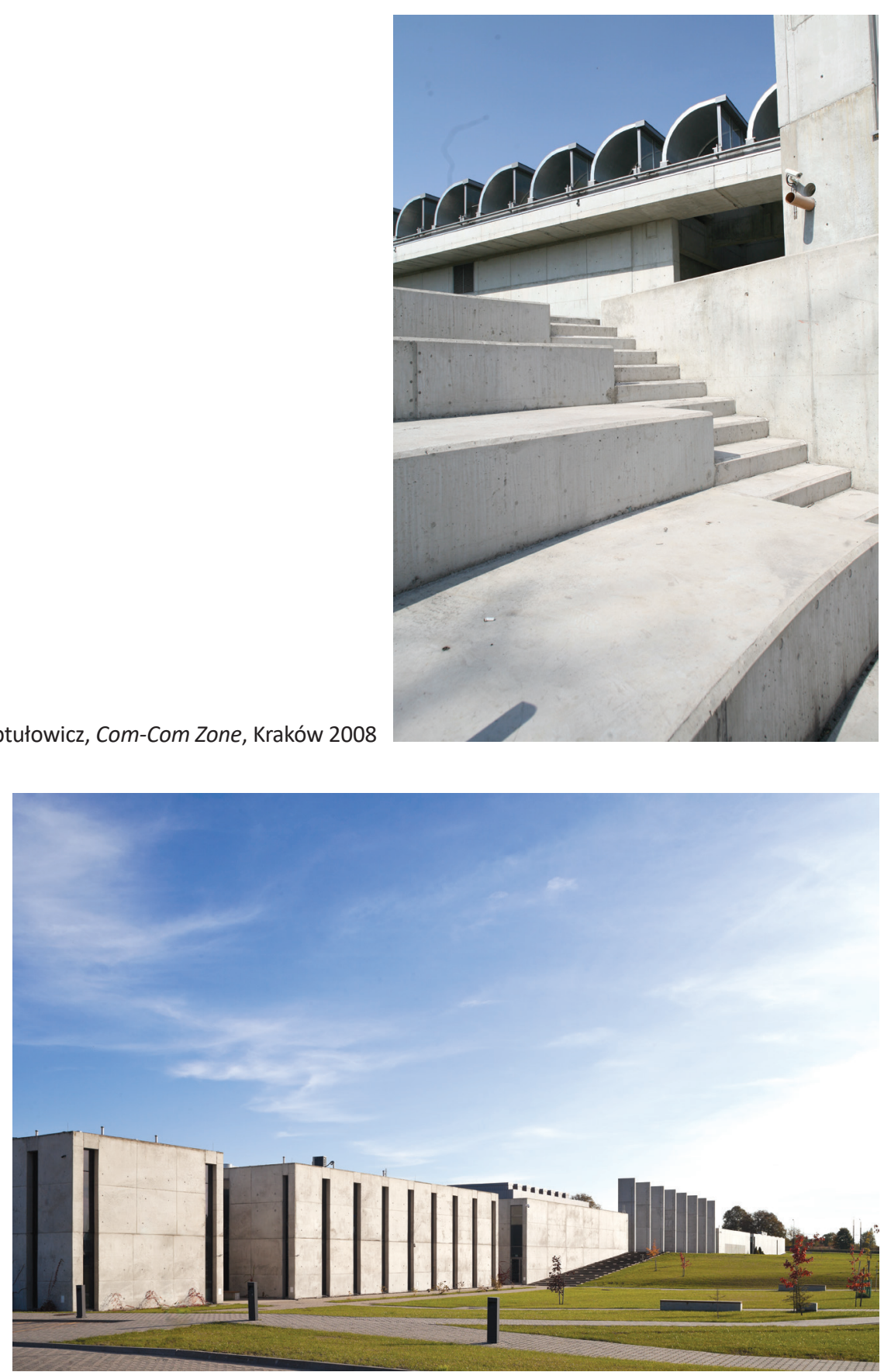

II. 12. B. Stelmach, Lubelski Park Naukowo-Technologiczny, Lublin 2014 


\section{PRZYPISY}

1 C. Simonnet, Le Béton en représentation - La Mémoire photographique de l'entreprise Hennebique 1890-1930, Paris 1993, s. 55-75; tłum. M.Ch.

2 R. McCarter, Louis Kahn and Nature of Concrete, "Concrete International" (32) 12, Farmington Hills 2009, s. 26-33; tłum. M.Ch.

3 D.B. Brownlee, Carnet du visiteur: Louis I. Kahn, le monde de l'architecte, Paris 1992, s. 69; tłum. M.Ch.

4 K. Frampton, Rappel à l'ordre; Głos w sprawie tektoniki, Czasopismo Techniczne 14-A/2011, s. 20.

5 Ibidem, s. 18.

6 Budynek otrzymał pierwszą nagrodę w konkursie na zagospodarowanie terenu Jordanek w Toruniu na cele kulturalno-kongresowe - wielofunkcyjna sala koncertowa zorganizowanym przez Gminę Miasta Toruń w 2008 roku.

7 W kościele św. Zbawiciela w La Laguna (2008) na Teneryfie wymyślona przez architekta mieszanka betonu i wulkanicznej skały picón canario nadała budowli mimetycznego charakteru w stosunku do specyficznych dla wyspy nieodległych wąwozów barrancos.

8 M. Merleau-Ponty, Oko i umysł. Szkice o malarstwie, Gdańsk 1996, s. 205.

9 Projekt zespołu Konior Studio zdobył pierwszą nagrodę w międzynarodowym konkursie na opracowanie koncepcji urbanistyczno-architektonicznej nowej siedziby Narodowej Orkiestry Symfonicznej Polskiego Radia w Katowicach w 2008 roku.

10 R. Twombly, Louis Kahn: Essentials Texts, New York-London 2003, s. 69.

${ }^{11}$ W 2010 roku jury międzynarodowego konkursu pod przewodnictwem architekta Daniela Libeskinda wybrało do realizacji projekt Studia Architektonicznego Kwadrat z Gdyni.

12 Pierwsza nagroda w międzynarodowym konkursie architektonicznym w 2005 roku.

13 Pierwsza nagroda w konkursie w 2009 roku na projekt rozbudowy i modernizacji muzeum w Michniowie w celu utworzenia Mauzoleum Martyrologii Wsi Polskich w Michniowie, organizowanym przez Muzeum Wsi Kieleckiej.

${ }^{14}$ E.H. Gombrich, Zmysł porzqdku. O psychologii sztuki dekoracyjnej, Kraków 2009, s. 18.

15 Z wywiadu udzielonego dla portalu Architektura Betonowa: „Wielu pyta o ten beton, czy mi nie zimno, czy ten beton daje radę. Odpowiadam, że wy również mieszkacie w domach z betonu, tylko o tym nie wiecie. To jest najczęściej stosowana technologia, ale potem obłożona tynkiem albo styropianem. Jesteśmy dokładnie w takiej samej przestrzeni w Arce jak wy w swoich mieszkaniach czy domach"; https://www.facebook.com/ArchitekturaBetonowa/ (dostęp: 28.07.2017).

${ }^{16}$ AD ARTIS Emerla, Jagiełłowicz, Wojda - pierwsze miejsce w konkursie na projekt urbanistyczno-architektoniczny i założenia ekspozycji Centrum Historii Ostrowa Tumskiego w 2009 roku. 
17 Według Petera Collinsa August Perret - jako pierwszy - nobilitował beton w kościele w Le Raincy, nazywając go materiałem szlachetnym [noble]. Architekt nazwał tę próbę ukształtowania formy w betonowym kształcie estetyką „surowości” [brut] lub „nagości” [nudité], w której odnajduje szlachetność, choć nie „nowoczesność”, [Za:] P. Collins, Concrete: The Vision of the New Architecture, Montreal 2004, s. 315.

18 Pierwsze miejsce w konkursie na projekt Młodzieżowego Centrum Sportu i Edukacji w Nowej Hucie w 2005 roku.

19 „Tutaj bardzo chciałem połączyć beton z drzewami, z zielenią, z krajobrazem, i chciałem, żeby to były połączenia BRUTALNE - bo właśnie one dają smak. One są jak czerwone wytrawne wino”, [Za:] „Budownictwo Technologie Architektura”, IV-VI'2011, Polski Cement.

20 B. Stelmach, Poszukiwanie struktur/In Search of Structures, t. 1: Prace architektoniczne 1997-2011/Architectural Works 1997-2011, PAN o/Lublin, s. 124-128.

\section{LITERATURA}

Brownlee D.B., Carnet du visiteur: Louis I. Kahn, le monde de l'architecte, Paris 1992, s. 69.

Frampton K., Rappel à l'ordre; Głos w sprawie tektoniki, Czasopismo Techniczne, 14-A/2011.

Gombrich E.H., Zmysł porzqdku. O psychologii sztuki dekoracyjnej, Kraków 2009.

McCarter R., Louis Kahn and Nature of Concrete, Concrete International, (32) 12, Farmington Hills 2009.

Merleau-Ponty M., Oko i umysł. Szkice o malarstwie, Gdańsk 1996.

Simonnet C., Le Béton en représentation - La Mémoire photographique de l'entreprise Hennebique 1890-1930, Paris 1993.

Stelmach B., Poszukiwanie struktur/In Search of Structures, t. 1: Prace architektoniczne 1997-2011/Architectural Works 1997-2011, PAN o/Lublin.

Artykuł w polskiej wersji językowej stanowi przedruk angielskiego oryginału publikowanego jako dwa artykuły:

Charciarek M., Forms, details and contemporary meanings of Polish concrete architecture, part 1, Technical Transactions, 4/2018, pp. 23-34.

Charciarek M., Formy, detale i współczesne znaczenia polskiej architektury betonowej, part 2, Technical Transactions, 4/2018, pp. 35-44.

ADRES BIBLIOGRAFICZNY ARTYKUŁU: Charciarek M., Nowe kooperatywne modele mieszkaniowe, Przestrzeń/Urbanistyka/Architektura, 1/2018, s. 71-94.

DATA AKCEPTACJI OSTATECZNEJ WERSJI DO OPUBLIKOWANIA: 6.04.2018. 